Rev. Grzegorz Strzelczyk

\title{
SYNODALITY: AN EPIPHANY OF THE SPIRIT
}

This article discusses the ecclesial phenomenon of synodality. The author focuses on the potential implications of synodality on ecclesiology and the life of the Church. Within ecclesiology, synodality identifies the sphere in which the Holy Spirit truly leads the Church. With regard to ecclesial practice, synodality helps us understand the role that the auxiliary structures of discernment (e.g., synods, councils) play and, consequently, properly shape the awareness of the members of these bodies. This article will present the ancient tradition of seeking consensus among these members as the proper way to make decisions from a pneumatological point of view as a moment of epiphany in which the inspirational action of the Holy Spirit who, by inspiring individuals, is manifested in decisions that concern the Church community.

Key words: ecclesiology, pneumatology, synodality, collegiality, synod.

Before discussing the main point of this article, I would like to clarify the concepts mentioned in the title that indicate the subject of this study. Firstly, I use the term "synodality" as Eugenio Corecco ${ }^{1}$ understands it in order to distance myself from the canonical connotations (and discussions about them) of the word "collegiality." Correco points out that using the term "synodality" can be useful because-in both his and my opinion-the concept of collegiality is frequently and unfortunately reduced to the sphere of acts collegially carried

E. Corecco, "Ontologia della sinodalità," in: Ibid. Ius et communio: scrittididiritto canonico, Casale Monferrato, Lugano 1997, pgs. 82-83.

2 See, for example, the debate concerning the issue of the collegial status of the bishop's conference, which J. Majewski describes well in Spór o rozumienie Kościoła. Eklezjologiczne uwarunkowania i perspektywy wielkich debat teologicznych na przetomie XX $i$ XXI wieku, Warszawa 2004, especially pages 209-212. 
out by those with the power to govern. The term "synodality" situates us within the more theological dimension of the misterium of the Church known as communio and also emphasizes a particular constant aspect of collegial life that is not entirely described by Canon Law and that, perhaps, is even a component of the essence of ecclesial unity: namely, when it is necessary to make a decision pertaining to the community (on the different ecclesial levels and independent of whether the ultimate decision must be made by one person or collegially in the strict canonical sense of this word), then the process of communal discernment of God's will in such a way that the decision will be in accordance with it takes place. In extraordinary conditions, this process may be "safeguarded" by the charism of infallibility, and in ordinary conditions it is subject to all of the weaknesses of human discernment.

In considering the epiphanal character of synodality, the institution of the synod, meaning both ancient and current synodal practice, is naturally of particular interest to us because it is the most concrete and self-aware as it were example of synodality. However, like E. Corecco, I believe that all forms of communal discernment and decision-making within the Church, even when they concern exclusively advisory bodies as well as non-institutional and temporary assemblies (in this regard, the subject of communal deliberation rather than the formal status of the assemblies is decisive), ${ }^{3}$ are (or at least may be) expressions of synodality.

However, Corecco's description of an "ontology of synodality," which I treat more as inspiration than a formal reference point, fails to mention a fundamental dimension: pneumatology. ${ }^{4}$ His complete silence in this regard has led me to consider this issue.

Secondly, in this study, we can understand "epiphany" to mean what the Catholic Encyclopedia states: "the revelation of the sacred by means of a reality that is different from it or with which it identifies." It is important to point out, however, that this entry mentions theophany and Christophany but says nothing about epiphany in relation to the Third Person of the Trinity. ${ }^{6}$ In this

3 Thus, even a casual meeting between two bishops manifests synodality insofar as they discuss matters pertaining to the life of the communities entrusted to their care. This is even more so the case if these communities are bodies bound by canon law such as diocesan and parish councils.

4 In the citation from Lumen Gentium (12), the Holy Spirit appears only in the footnote. In this regard, por. E. Corecco, Ontologia della sinodalità, op. cit., pg. 107.

$5 \quad$ J. Szlaga, "Epifania," in Encyklopedia Katolicka, vol. IV, Lublin 1985, k. 1020.

6 Naturally, it is difficult to pose serious objections to the author of this entry because there was insufficient space for him to fully develop the various possible topics. 
context, my considerations can contribute to the Christian understanding of epiphany.

It is difficult to begin my discussion without first pointing out one fact: current dogmatic ecclesiology discusses synodality, particularly how it is manifested in a synod, rather sparingly, if at all. It seems that dogmatists have relinquished the playing field to canonists in this instance. ${ }^{7}$ But this article is neither the time nor the place to discuss the consequences of this state of affairs. $^{8}$

Finally, the working hypothesis of this study is as follows: the phenomenon of synodality-a phenomenon which is part of ecclesial praxis in terms of what concerns administration by communities (in the doctrinal sense as well)-is not exclusively nor even primarily a human act of administration. Rather, in its very essence, synodality is associated with the possibility of an epiphany of the Holy Spirit. ${ }^{9}$ In other words: every gathering in which the synodality of the Church is realized is (at least potentially) an epiphany of the Holy Spirit. Moreover, expectation of this epiphany should be the reason for such a gathering.

It is possible to adopt this hypothesis and make arguments in its favor insofar as they are based on the following preliminary and universal assumption: the Holy Spirit has and will continue to guide the Church throughout the ages. The Second Vatican Council expressed this in the following way: "Moving forward through trial and tribulation, the Church is strengthened by the power of God's grace, which was promised to her by the Lord, so that in the weakness of the flesh she may not waver from perfect fidelity, but remain a bride worthy of her Lord, and moved by the Holy Spirit may never cease to renew herself, until through the cross, she arrives at the light which knows no setting." 10 Certainly, the statement that the Holy Spirit guides the Church is easier to accept the more generally it is known and broadly understood. However, it is important to note that we are not speaking about an abstract patronage but rather a concrete influence that truly forms the life of the Church. Again,

$7 \quad$ E. Corecco's article cited above is a good example of how canonists are in fact forced to do independent research on ecclesiology due to the inadequacies of systematic ecclesiology.

Undoubtedly, certain undesirable consequences of this state of affairs are easy to point out. The first is the undoubted domination of a formal and legal approach to decisionmaking processes in the Church over an approach that one could call epiclectic-one in which the inspirations of the Holy Spirit are consciously sought, listened to, and discerned, rather than the pragmatic principles of administration.

9 We can speak not only about the "possibility" but also the certainty of such an epiphany in some cases where the charism of the infallibility entrusted to the Church is consciously involved.

10 Second Vatican Council, Lumen Gentium 9. 
when we speak about the "life of the Church," we are referring to the ways in which it is tangibly manifested broadly from the universal Church to narrowly in the everyday life of a diocese, parish, or even small ecclesial communities. And, if we ask how the Spirit's influence is accomplished in practice, then we arrive at a point that is essential to our considerations: saying that the Holy Spirit guides the Church implies that the Spirit actively participates in the human decision-making process. In other words, the Spirit seeks to reveal to the community God's plan for it, while the community-on its part-has the opportunity to discern, understand, and put the Holy Spirit's inspiration into practice. ${ }^{11}$

It is important to note that the way in which the Holy Spirit "reveals" Himself, whether as a "private revelation" or as prophecy, which is one way that the extraordinary charismatic forms of knowledge is manifested, usually does not occur in an epiphanic way. Moreover, even in these extraordinary cases, it is the practice of the Church-in keeping with the New Testament-to maintain a certain distance from these occurrences and to require that the authenticity of the knowledge obtained in this manner be verified. ${ }^{12}$ This verification is even more necessary in cases where the inspiration of the Holy Spirit, Who can lead the Church to the "complete truth" (John 6:13), occurs in such a subtle manner that the person experiencing these inspirations cannot be sure of their source, or occurs in an even subtler manner through the strengthening and directing of man's innate cognitive powers. ${ }^{13}$ For this reason, the verification process-typically known as "discernment"-is indispensible; for, it is in this process that interior "movements" can be discerned as coming from the Holy Spirit, or not.

Typically, discernment is used in reference to a person's individual search for God's will. Even in this context, however, is its preferable that at least

11 The limited scope of this study makes it impossible to address how such communication that results in a new way of knowing is possible as well as the anthropological structures that make it possible. Theology has continued to reflect uninterruptedly on this issue throughout time. And, in recent years, interest in the concept of "spiritual senses" has increased (por., for example, The Spiritual Senses: Perceiving God in Western Christianity, P. L. Gavriluk, S. Coakley, eds., Cambridge 2011). Here, however, one simple constant is enough: without affirming this possibility, Christianity as such would be inconceivable because Revelation would be inconceivable.

12 Lumen Gentium (12) and the Catechism of the Catholic Church (801) point out that the authenticity of the charisms as well as the ways in which they are used in the Church belong to the Church's pastors.

13 Here is not the place to discuss all of the possible ways that the Holy Spirit's inspirations are imparted to individuals. Again, we are more interested in the fact that this is possible. The way in which this happens is primarily the interest of the field of theology of spirituality. 
some kind of community, even if only a spiritual director, verify an individual's discernment. ${ }^{14}$ Communal discernment is all the more useful, if not necessary, when decisions that pertain to a community-from the smallest to the universal Church-are being made.

At this point, the following reasonable question arises: What makes communal discernment more worthwhile (and also: effective) than individual discernment by itself? Naturally, human wisdom provides a response to this question in the well-known idiom: "Two heads are better than one." From a theological perspective, however, it is important to consider another dimension: If, "God [...] does not make men holy and save them merely as individuals, without bond or link between one another. Rather, it has pleased Him to bring men together as one people..." 15 , and the Spirit leads through history and the community of the Church (and not Christian monads), then one can expect that this same Spirit will evoke through many members and in various ways movements that lead in one and the same direction. In other words, through the communal discernment process, individual insights coincide with each other and this reveals direction in which the Holy Spirit desires the community to go. Coming to a communal consensus, of which the aim is discerning God's will, is not achieved by compromising individuals' positions. Rather, it occurs through the revelation of the Holy Spirit's singular thought revealed to the community, which is discerned first by particular individuals, and then made manifest in the full syntony of these individual discernments. Those who are moved by the Holy Spirit in this direction will converge sooner or later, and this is the meaning behind the term "syn-hodos" ("together-journeying," synod). Synodality, therefore, occurs when thoughts and ideas come together; in short, it is discernment through agreement.

The ancient synodal practice of making decisions through the process of coming to full agreement expressed either through acclamations or through the statements of all those assembled is, in my opinion, a practical expression of the aforementioned understanding of the essence synodality as the rule for making decisions within the community of the Church. Synodality is fundamentally and essentially different from modern democracy where the majority is "right." Synodal "rightness" is always on the side of the Holy Spirit. Yet, as a human process of discernment-with the exception of those who enjoy the safeguard of the charism of infallibility-it is prone to error and, therefore,

14 For example, in the $13^{\text {th }}$ rule of the first week of the Spiritual Exercises, St. Ignatius of Loyola suggests that revealing inner movements to one's confessor or others is one way to avoid the tricks of the devil.

15 Second Vatican Council, Lumen Gentium, 9. 
as sometimes occurs, the true movement of the Spirit can be ignored, ${ }^{16}$ for example, because the dismissed minority within the assembly expressed it. The history of both doctrinal and disciplinary ancient synods contains many such examples. ${ }^{17}$ Nevertheless, the history of these synods also teaches us that the Spirit ultimately prevailed over time through the broader community's discernment; through the process of discernment that took place through the horizontal reception (by neighboring communities) or vertical reception (by metropolitans or patriarchs) of the decisions made by synods; or, finally, through the charism of infallibility.

I believe, therefore, that there is sufficient evidence that the moment in which God's design becomes clear to the community through unanimity of thought arrived at through communal discernment exists. I also believe that this moment can be called an epiphany in the strict sense of the word. For, one cannot interpret God's will in any other way than through the actual aid of the Holy Spirit Who reveals Himself and, in so doing, manifests God's plans. ${ }^{18}$ Obviously, this epiphany is not spectacular event that is confirmed and strengthened through physical phenomena as was the case on Pentecost. On the other hand, I would beg the question: Is not arriving at synodal consensus in itself spectacular enough, particularly when we consider that this happens through the acts of humans who were not necessarily inclined to be of one mind when their discernment commenced?

It is important to point out that unanimity should be treated here as the final stage of the path of discernment and should be distinguished from a consensus that passively maintains the status quo. Within the Church, the Holy Spirit awakens creativity in continually new contexts; for this reason, it is extremely important to be open to different and uncomfortable opinions at the outset. The criterion, "But it has always been done this way," cannot serve as the basis for discernment-it cannot block bold and creative new ways of doing things. ${ }^{19}$ These new ways of doing things should be considered epiphanal,

16 Thus, metanoia plays a significant role here; for, it involves particular members of the synodal assembly aligning their minds and hearts with the Spirit of the Lord. In other words, it requires their sanctity.

17 I will limit myself to one example: in $355 \mathrm{AD}$, Eusebius of Vercelli was one of only a few bishops who professed Nicene faith and opposed the Arian majority at the Synod of Milan. The synod ignored his opposition, and the emperor sent him into exile.

18 Por. Second Vatican Council, Dei Verbum, 2. This document suggest that God's personal self-disclosure consistently precedes and is the condition for the possibility of obtaining any knowledge about God in the logic of revelation.

19 Por. Francis, Evangelii Gaudium 33. 
even if the authenticity of the Spirit's inspiration is confirmed only through a longer process of discernment.

Naturally, the question arises: Can the self-awareness of the members of synodal assemblies confirm an epiphany of the Holy Spirit understood in this way? Before we arrive at the answer to this question, however, it is worthwhile to consider one secondary but, in my opinion, important caveat: a broad understanding of synodality that properly encompasses all Church advisory and decision-making bodies would seem to conflict with traditional canonical practice, which reserves the right to participate and vote in a synod to bishops only. If, however, this broader understanding of synodality is to be consistently pneumatocentric, then it is not only avoids this conflict, but, even more, emphasizes the special role of the bishop (as well as the priests who represent him in the lower-ranking bodies), provided that the ecclesial relationship between the bishop and the Holy Spirit is articulated correctly. Needless to say, I cannot develop this topic further here, so I will limit myself to mentioning only one liturgical moment that symbolically portrays this relationship. When the bishop consecrates the chrism oil, he breathes on it, which symbolizes the ecclesial and creative breath of Christ (por. John 20:22). Chrism is a sacramental symbol (Baptism-Confirmation-Ordination) of the Holy Spirit's effectiveness in the Church that is passed down through apostolic succession. The Bishop breathes the Spirit on the chrism oil-the very same Spirit who was sacramentally imparted to him and is imparted sacramentally to the Church through his service. ${ }^{20}$ If, therefore, the bishop plays a special role in the communal discernment process, then it is precisely because he plays a special role in imparting the Holy Spirit Who is revealed in this process. Consequently, the priest who participates in the bishop's sacramental service also participates in his responsibility to discern and represent the bishop's authority to the community entrusted to him. Emphasizing the pneumatological and ecclesiological dimension of the Sacrament of Holy Orders reveals that, if, for example, the bishop asks priests who are members of a priestly council or the laity who are members of a diocesan pastoral council to share their opinions, then he is essentially asking them to "return" the Spirit that he himself (or his predecessor) imparted to them. The bishop summons the Spirit within them and through them. In the conclusion, I will return to the issue of the importance of this insight.

$20 \quad$ Here I am not asserting that the Holy Spirit cannot act more broadly outside of the sacraments or outside of the visible confines of the Church. The fact that the Holy Spirit can act outside of the sacramental order in no way diminishes the primacy of the sacraments in the transmission of the Spirit. 
Let us now return to the question of the signs of the Holy Spirit's presence and action-His epiphany-among the members of a synodal assembly. At this point, the well-known expression "It is the decision of the Holy Spirit and us" that was made at the so-called Council of Jerusalem (por. Acts 15:28) comes to mind. However, due to the particular character of this council and the entire apostolic period, this argument alone is insufficient. Is there evidence that members of lower-ranking assemblies with less authority had this same insight of the Holy Spirit?

Although scarce, since the majority of early synods did not leave behind any meta-reflections on their own status, the documents (proclamations or synodal letters) from these synods, ${ }^{21}$ which took place in different centuries and territories, ${ }^{22}$ nevertheless contain explicit references to the causative presence of the Holy Spirit that are purely rhetorical. One of the oldest pieces of evidence comes from a period of Christian persecution (Carthage, $252 \mathrm{AD}$ ). Although the citation contains a clear reference to the charismatic dimension, it does not suggest that the Holy Spirit was invoked purely out of courtesy or custom:

So that from our lips, by which we withhold peace and, instead, express the harshness of human cruelty rather than divine fatherly gentleness, the Lord did not demand the sheep entrusted to us, through the inspiration of the Holy Spirit and under the influence of numerous visions and clear admonishments of the Lord, on account of the presaged and anticipated persecution, we have decided... ${ }^{23}$

Direct references to the presence and/or inspiration of the Holy Spirit can also be found in the East: "we have decided (...) in the presence of the Holy Spirit,"24 "it is pleasing to us and to the Holy Spirit"25 (Cabursusi, 393), "it has pleased the Holy Spirit, who is within us"26 (Bagai, 394), and in the West: "therefore, in the presence of the Holy Spirit, we have decided" (Arles, 314), ${ }^{27}$ and "what we think through the inspiration of the Holy Spirit"28

21 Unfortunately, it is not possible to study whether in early Christianity other types of assemblies were aware of the effective aid of the Holy Spirit as it is understood today due to a lack of sufficient primary sources.

22 We are dealing neither with the local tradition of some kind of community only, nor with the theological trend of a given historical period.

23 Acta Synodalia, I,11. Abbreviated hereafter as AcSyn.

24 AcSyn IV, 58.

25 AcSyn IV, 59.

26 AcSyn IV, 64.

27 AcSyn I, 69.

28 AcSyn IV, 61. 
(Rome, 447). The synodal letter of Council of Antioch in 341 AD witnesses to the conciliar fathers' hope that the Spirit will ensure that other communities will unanimously accept their decision: "we have now brought to your knowledge,; trusting in the grace of Christ and in the Holy Spirit of Peace, that you also will agree with us and stand by us as far as in you lies, striving with us in prayers, and being even more united with us, following the Holy Spirit, uniting in our definitions, and decreeing the same things as we; you, in the concord which proceeds of the Holy Spirit, sealing and confirming what has been determined." 29

The Council of Seleucia (Seleucia-Ctesiphon, 420) is a very interesting example of a case where the Church at that time was receptive to Western canons. In this context, the following synodal theory is evident: "When the bishop fathers gathered with pure intentions at different times for this holy synod, they declared the provisions necessary for reform, [and] the Church's constitution and legal regulations. Thanks to the grace of the Divine Spirit they established the law..." ${ }^{30}$ When speaking about itself, the synod indicated that it was awaiting the Holy Spirit, ${ }^{31}$ and when referring to the fathers of the synod, it indicated that they were inspired by the same Spirit. ${ }^{32}$

All of the evidence above confirms that the members of the ancient councils were aware that the Holy Spirit was in them and present through them and that He directly inspired them to make certain decisions. If the essence of epiphany is to reveal the sacrum through a reality that it is different from it, then can this not be considered an epiphany of the Holy Spirit through the synodal assembly? I believe that this can and should.

In conclusion, it is worthwhile to emphasize two essential prospects that, in my opinion open man up to the concept of synodality understood as an epiphany of the Spirit. Firstly, a very broad pneumatocentrically-oriented understanding of synodality makes it possible to better establish ecclesiologically different kinds of decision-making and conciliar bodies that do not constitute a synod of bishops in the strict sense. Experts in canon law find it difficult to find a proper place for these bodies in their field, and dogmatic ecclesiology seems barely acknowledge their existence. Is this not why diocesan synods, priestly councils, diocesan and parish pastoral councils, etc. are unable function properly? Because an adequate theological model does not exist, the principles upon which lay bodies-whether political (democratic) or economic

\begin{tabular}{ll}
\hline 29 & AcSyn I,134. \\
30 & AcSyn IV, 279 \\
31 & See AcSyn IV, 281. \\
32 & See AcSyn IV, 280.
\end{tabular}


(utilitarian)-function are often applied to ecclesial assemblies. As a result, they are unable to express the essence of the Church (or, in other words, to receive the Spirit). And, while they are beneficial insofar as they sometimes improve management, these principles are insufficient because they contribute to the confusion that exists about vocations and roles, and they also cause members of collegial (and especially advisory) bodies to become frustrated. This often very negatively influences the relationship between priests and their bishop, or the laity and their pastor. After all, it is precisely those who must singlehandedly (hierarchically) make decisions in consultation with advisory bodies who can benefit most from the adoption of a pneumatic model of interpretation. Such a model will make it is easier to realize the sense and value of these bodies and the benefit of consulting them.

Secondly, an epiphanal understanding of synodality makes it possible to look at ecclesial decision-making and advisory bodies more with their theological and spiritual role in mind. This approach can partially serve as a remedy to the disease of functionalism that affects these bodies perhaps too frequently. Aware that an epiphany is possible, the prayer to the Holy Spirit which is usually prayed to open each session should become an intentional epiclesis-a calling down of the Holy Spirit in preparation for His actual coming and His manifestation in communal discernment and unanimous agreement. If openness of the will is at least partly a feature of self-insight, then it also follows that the theological model that co-determines this insight plays a considerably decisive role in the effectiveness of synodal bodies.

Słowa kluczowe: eklezjologia, pneumatologia, synodalność, kolegialność, synod.

\section{Bibliography:}

1. Corecco E., Ontologia della sinodalità, in: E. Corecco, Ius et communio: scritti di diritto canonico, Casale Monferrato, Lugano 1997.

2. Francis, Evangelii Gaudium, Vatican 2013.

3. Majewski J., Spór o rozumienie Kościoła. Eklezjologiczne uwarunkowania i perspektywy wielkich debat teologicznych na przełomie XX $i$ XXI wieku, Warszawa 2004.

4. Second Vatican Council, Dei Verbum, Vatican 1965.

5. Second Vatican Council, Lumen Gentium, Vatican 1964.

6. Szlaga J., Epifania, in: Encyklopedia Katolicka, vol. IV, Lublin 1985, k. 1020.

7. The Spiritual Senses: Perceiving God in Western Christianity, P. L. Gavriluk, S. Coakley, eds., Cambridge 2011 